\title{
ELLIPTICAL AND SICKLE-SHAPED ERYTHROCYTES IN THE CIRCULATING BLOOD OF WHITE PERSONS
}

BY JOHN S. LAWRENCE, M.D.

(From the Departments of Medicine and Anatomy, Vanderbilt University School of Medicine, Nashville, Tennessee)

(Received for publication July 5, 1927)

\section{INTRODUCTION}

The normal erythrocyte is so uniform in shape that variations from the normal have been widely accepted as evidence of pathological conditions. Among the most striking of these variations are the changes in size and shape which occur in pernicious anemia. These variations do not, however, have any single characteristic type but are of almost unlimited diversification. On the other hand, there have been reported cases in which there were variations in the shape of the red blood cells which were wholly characteristic, and in which most of the abnormal cells were quite alike. The most important entity of this type is the so-called sickle cell anemia, the first case of which was described by Herrick (1910). Numerous other cases have been described since then by Huck (1923) Sydenstricker (1924), and others, and in all of these cases the deformed erythrocytes have been, in general, quite similar. The characteristic type of the sickle cell is well known. Another type of erythrocyte is the oval type which has been especially prominent in the cases reported by Dresbach (1904, 1905), Bishop (1914), and by Huck and Bigelow (1923), respectively. The type of these cells can be seen in Bishop's illustration (fig. 1). Finally, there have been seen, from time to time, long slender cells, especially in cases of secondary anemia. These cells have been noted in particular by Minot and Lee (see Plate V, preceding page 3, Nelson Loose-leaf Living Medicine, Volume IV). Thus it would seem that the red blood cell, which under normal conditions maintains its biconcave shape with such remarkable regularity, is capable of being modified in shape in quite characteristic patterns. The exact nature 
of the conditions producing these changes is not known, but a number of factors have been suggested as of etiological significance. Disorders of blood formation and the presence of abnormal substances in the serum have been suggested as possible causes of deformed red blood cells. Another important consideration with regard to etiology is the question of racial distribution. Pernicious anemia is much more common in the white race but has been reported in negroes. Sickle cell anemia has only been seen in negroes, and many observers have felt that, in this condition, the racial element was one of great significance. In addition to this racial distribution a familial distribution has been noted also; e.g., sickle cells have been found with great regularity in the families of patients having typical sickle cell anemia. This finding of deformed erythrocytes in apparently normal individuals has opened up an important question as to whether the causative agent of the pathological conditions may not be, at least in part, a predisposition - in nature, racial or familial, or both. Cooley and Lee (1926) found sickle cells in ".5 per cent of negro patients. Sydenstricker and his coworkers (1923) have stated that they have found latent sickling 13 times in examining over 300 negroes.

The present investigation, resulted from the study of a case of moderate anemia in a white woman, characterized by the presence of numerous sickle and elongated erythrocytes. Unfortunately, this case was only studied for a very short time and many of the confirmatory examinations that would have been desirable were not obtained. However, the case was sufflciently marked to suggest examination of the patient's family. One sister, one brother and one niece were found to have both sickle and long, slender erythrocytes, while negative results were obtained in the blood of one brother and one sister. In addition to this case, five other white patients in the Vanderbilt Hospital (see table 1) have been found to have sickle or elliptical shaped erythrocytes, though in none of these have the cell changes been as marked as in the one case referred to above. These findings suggested the possibility that the deformed red blood cells seen in the patient referred to above, and in her relatives, might represent a mild form of sickle cell anemia or of some intermediary condition. Since the importance of the racial factor in this form of anemia had been stressed, and since the analysis of blood of normal 
negroes had yielded the presence of sickle cells, the examination of a series of normal whites and negroes was undertaken to determine just what evidence of similarity or difference could be found in this regard. In brief, the results obtained indicate that in the case of normal individuals of the two races studied, there is very little difference, a slightly higher percentage of deformed cells having been found in the white than in the colored individuals in the cases examined.

\section{REPORT OF CASE}

Case 1. L. B. S. The patient was an American-born, white woman of Spanish and Scotch-Irish descent, 32 years of age, who came into the hospital complaining of disability in walking. Her health had been very good until about ten months before entering the hospital. She had been troubled with soreness of the mouth, and bleeding about her teeth had occurred at times for several years. She had had hemorrhoids for about five years, these had bled once or twice every month, but not profusely. Her menses had been profuse, and usually lasted from seven to nine days. She was the mother of three children, the first of whom was stillborn, the other two were living and well, aged 14 and 10 years. Her present illness began about ten months before her admission to the hospital, with a respiratory infection which she thought was influenza. Following this infection she felt tired and weak at intervals for about three months. About four and one-half months before admission to the hospital she noticed that she could not walk as well as before. She felt dizzy and there was some trembling.

Physical examination. She was a pale undernourished white woman. Her temperature, pulse and respiration were normal. The mucous membranes were slightly pale. The head showed no abnormalities. The tonsils were moderately large and embedded. The neck presented no abnormality except that the posterior cervical lymph glands were palpable. The chest was symmetrical and the lungs presented no abnurmalities. The heart showed no marked systolic shock. On percussion, the borders were outlined $2.5 \mathrm{~cm}$. to the right and $8 \mathrm{~cm}$. to the left in the fourth intercostal space. There was a soft systolic murmur at the apex, and in the second interspace on the left there was a loud blowing systolic murmur. At one time in this same area a loud diastolic murmur filling the whole of diastole and transmitted out toward the shoulder was heard. The rate and rhythm were normal. The blood pressure was $116 / 70$. The abdomen was normal in contour. No areas of tenderness were found. The liver and spleen could not be felt. The extremities presented no abnormalities. There were no leg ulcers. On first standing, the patient fell backward to the right. After walking, she was steady with her feet together and there was only slight swaying on closing the eyes. When she was told that she was falling to the right, she did, and yet, when support was withdrawn she steadied herself. When walking she was unsteady on turning when near the examiner, but when at the other end of the walk she was steady. 
The finger to finger test was performed better with the eyes closed than with them opened, but here again, the right side was more at fault.

The blood. The red blood cell count was 3,850,000 per cubic millimeter. The white blood count was 8,900 per cubic millimeter. Hemoglobin 45 per cent (Sahli). A smear stained by Wright's technique showed the red blood cells to have moderate achromia. There was slight anisocytosis, the average size being normal. There were some small cells but no very large ones. There was rarely a cell that was polychromatophilic. The most striking finding was the decided tendency of the erythrocytes toward sausage forms. The platelets were apparently normal. The differential count was: polymorphonuclear neutrophiles 64 per cent, polymorphonuclear basophiles 1 per cent, lymphocytes 22 per cent, monocytes 12 per cent. A fresh, sealed preparation was examined about one hour after it was taken, and the following findings were noted. Most of the erythrocytes were fairly uniform in size. Only a few small forms were seen and none of very large size. From 5 to 10 per cent of the red blood cells were definitely sickle or sausage shaped, some having blunt and rounded ends, others having typical pointed ends. All transitions from the typical sickle cell to the round normal erythrocyte were seen. Many of the abnormal cells had slender processes, from 1 to 10 micra in length, which were obviously attached to the membrane of the cells. These were more marked in the crescent forms, and in addition were in many instances seen free in the plasma. The polymorphonuclear neutrophiles showed a definite increase in motility and contained numerous vacuoles, which showed in many instances a definite hemoglobin color. In many of the leucocytes, both short and long rod-shaped structures were seen (some in the vacuoles mentioned above and some elsewhere in the cytoplasm). While these structures could not be identified absolutely as such, they seemed to be the long and short rods mentioned above, which had been broken off from the abnormal red blood cells. No nucleated red cells or myelocytes were seen. Many fragmented cells and shadow cells were present. Figures 1, 2, and 3 show some of the characteristic findings in a stained blood preparation from this patient.

It is of interest that one brother, one sister, and a niece of this patient gave evidence of the same peculiarities of the erythrocytes. However, this phenomenon was not so marked among these individuals as it was in the patient. It is unfortunate that ignorance and superstition on the part of the family prevented further study of the patient's blood and the examination of the blood of other members. Figure 4 shows a sausage-shaped cell found in the blood of one of the patient's sisters. The remaining five cases are grouped in table 1 . Examination of this table shows that these patients represent a variety of pathological conditions and are of both sexes. There does not seem to be any obvious relationship between these cases, 


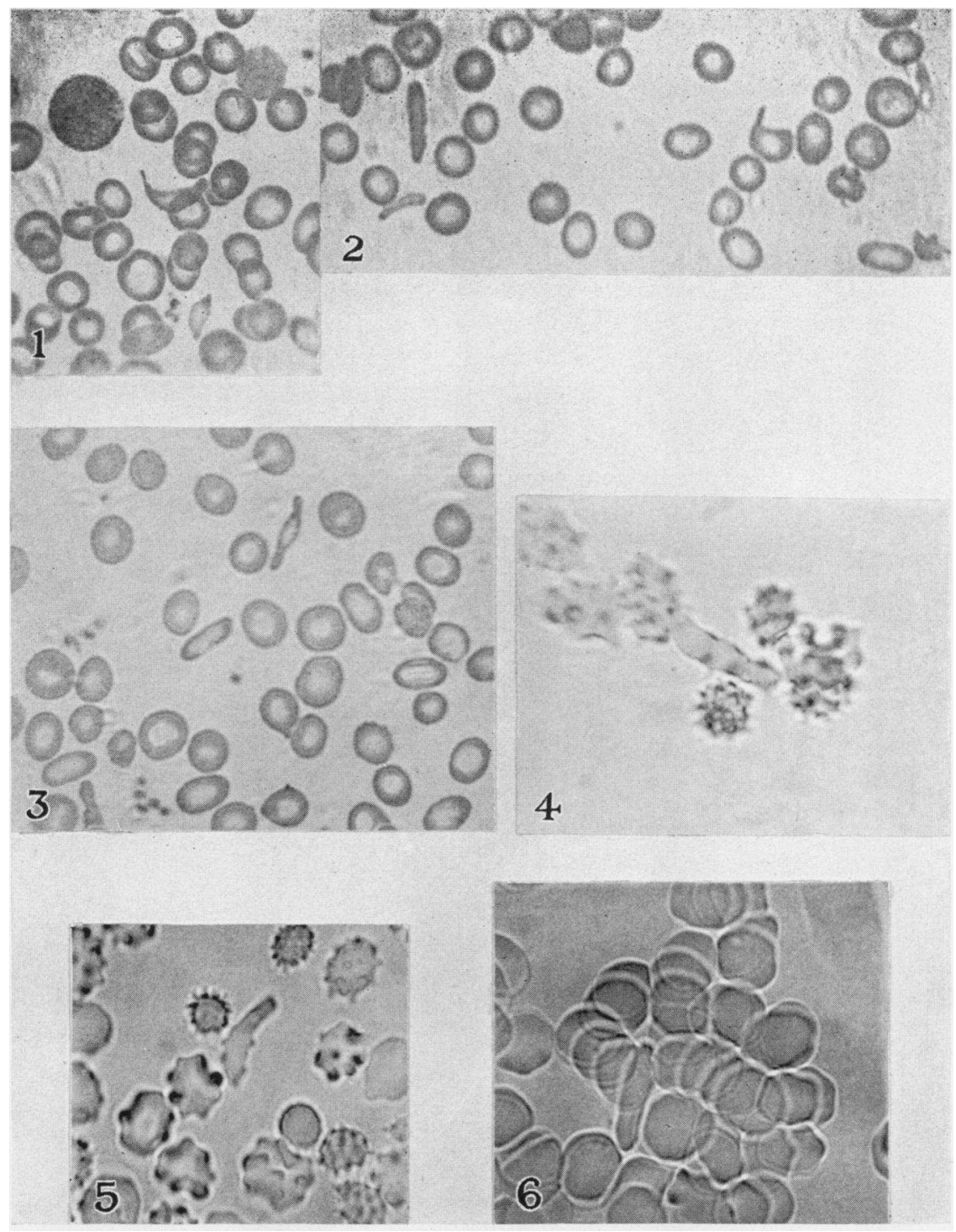

Fig. 1. Microphotograph of a Stained Smear of the Blood from Case 1, L. B. S. $\times 600$

Fig. 2. Microphotograph of a Stained Smear of the Blood from Case 1, L. B. S. $\times 600$

Fig. 3. Microphotograph of a Stained Smear of the Blood from Case 1, L. B. S. $\times 600$

Fig. 4. Microphotograph of a Fresh Sealed Preparation of the Blood From ONe of the Sisters of Case 1, L. B. S. $\times 1000$

Fig. 5. Microphotograph of a Fresh Sealed Preparation of the Blood From A. L. S. (TABlE 1). $\times 1000$

Fig. 6. Microphotograph of a Fresh Sealed Preparation of the Blood FROM W. D. A. (TABle 1). $\times 1000$ 


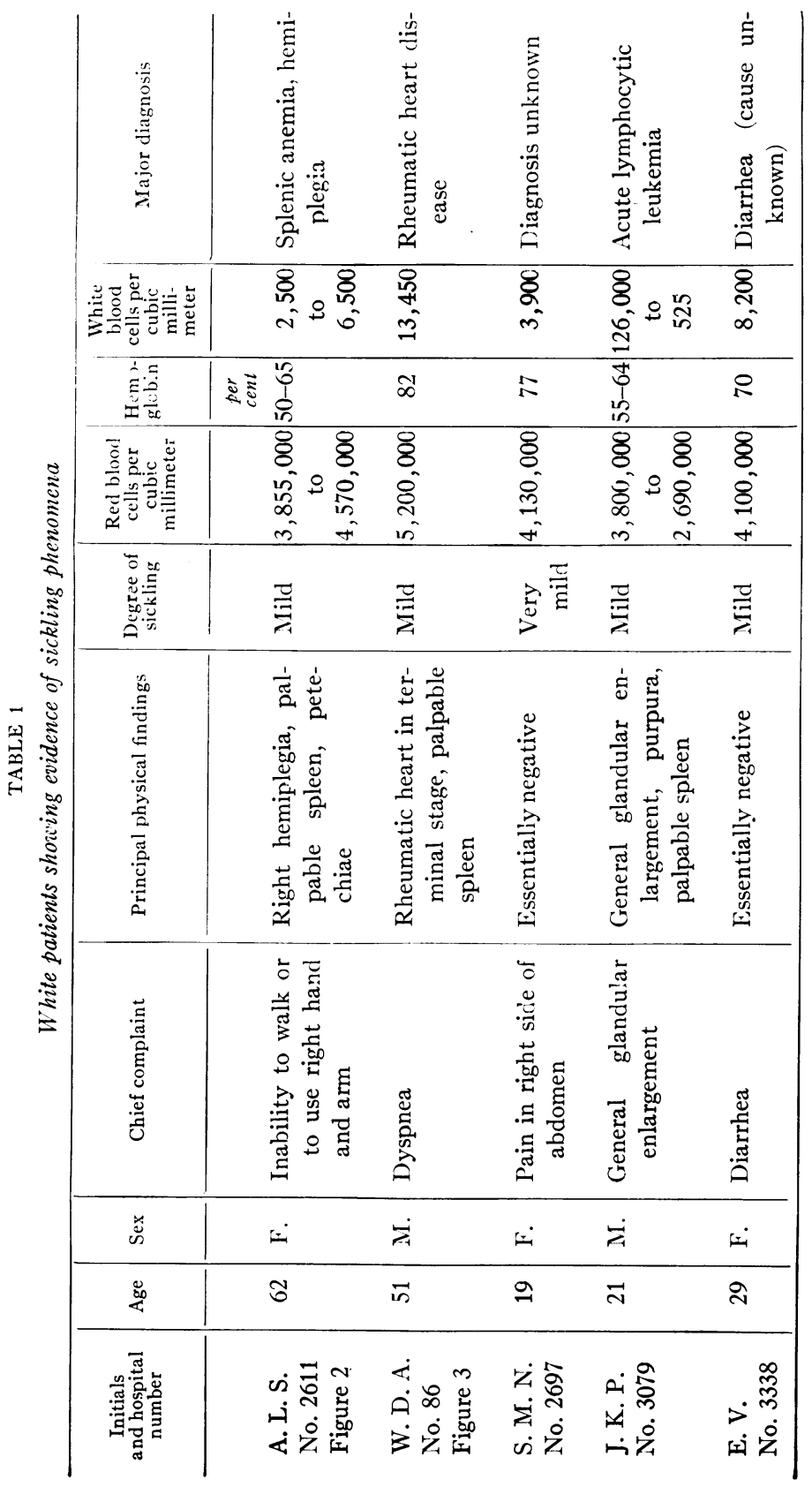


but the series is too small to be utilized for any general conclusion regarding the type of case in which such changes may occur. It is hoped that a larger series of hospital cases may be examined later with the object of determining whether these cells are found with any regularity in any particular clinical entities. Figure 5 represents one of the cells found in a fresh sealed preparation from A. L. S. Figure 6 shows a field in a fresh sealed blood preparation from W.D.A.

APPARENTLY NORMAL WHITE PEOPLE SHOWING CHANGES IN RED BLOOD CELLS (SUBJECTS 2, 3 and 4)

Since elliptical and sickle shaped erythrocytes were found to be definitely present in white patients it seemed advisable to extend this study to a series of normal white individuals. Accordingly, 102 normal white adults were examined. A comparative series of 98 negroes was studied also. The normal white subjects consisted of medical students of the Vanderbilt University Medical School, and thirteen nurses of the Vanderbilt Nursing School. Three subjects (subjects 2, 3 and 4) who showed elongated or sickle cells were found. In no case where these changes were found was a single observation relied upon, but many examinations were made at varying times with the same results on each observation.

Subject 2. M. C. The first of these individuals showing these characteristic cell changes was a white girl, 18 years of age, a student in the School of Nursing. She was in good general health. General physical examination was essentially negative. There was no generalized glandular enlargement. The spleen was not palpable and there was no discoloration of the sclerae. A fresh sealed preparation of whole blood on December 1, 1926, showed a number of sausage forms and slight filamentation without sickle shaped cells. Another fresh sealed preparation on December 2,1926, showed a few sausage cells but no sickling and no filamentation. A third examination on January 25,1927 , revealed similar findings. On this date the other blood findings were: red blood cells 4,880,000 per cubic millimeter; white blood cells 12,500 per cubic millimeter; hemoglobin 75 per cent. A smear stained by Wright's technique at this time showed a small number of sausage forms. No very long cells, no filamentation and no changes in the staining reaction were seen. There were no abnormal variations in the size of the erythrocytes. The platelets were normal. Differential count: polymorphonuclear neutrophiles 67 per cent; polymorphonuclear eosinophiles 5 per cent; polymorphonuclear basophiles 0 per cent; lymphocytes 25 per cent; monocytes 3 per cent. Figures 7 and 8 show the typical red blood cells seen in this subject. Figure 8 shows a sausage cell which has persisted even though crenation has occurred. 
Subject 3. H. B. McS. The second subject was a medical student, male, 21 years of age, who was in good health. His past history revealed no chronic illness, nor had he ever had jaundice. He had been feeling perfectly well. Nine years previously, for a day or two, his joints had been painful but without swelling or redness. There was no other history of joint symptoms. He had two sisters living and well. There was no history of serious illness among his relatives. Careful physical examination was essentially negative. There was no jaundice, the spleen was not palpable, and there was no general glandular enlargement.

The blood. The red blood count was 4,970,000 per cubic millimeter. Hemoglobin 80 per cent (Sahli). Smear stained by Wright's technique showed the red blood cells to have normal staining characteristics. There was no achromia. Throughout the smear, at fairly frequent intervals, were definite pencil or sausage shaped cells, but these did not tend to be as long as the ones seen in the fresh preparation, the longest one being possibly a little less than twice the diameter of the average red bluod cell. There was moderate but very definite filamentation. No true sickle cells were seen. The average size of the red blood cells was normal but rare microcytes were present. No macrocytes were seen. The platelets were normal. A fresh sealed preparation examined on November 29, 1926, showed fairly frequent sausage forms and a few definitely characteristic sickle cells. There was some filamentation. A second fresh sealed preparation was examined January 24, 1927, and at this time definite sausage forms were present in fair abundance. A few sickle cells were also seen. Moderate filamentation was present. On February 24, 1927, a fourth fresh preparation was examined with essentially the same findings as above. Icteric index was 6 . Figure 9 illustrates the cells found in this subject.

Subject 4. J. C. McK. The third individual in this series was a medical student 23 years of age. He was in good health. There was no history of jaundice nor was there any history of arthritic manifestations. Beginnng on the third or fourth day after tonsillectomy, he had bled off and on for about one week. There was no history of bleeding at any other time, nor was there any history of bleeding in the family or among the relatives. The patient had been smoking somewhat excessively. Physical examination revealed irregular cardiac rhythm. In other respects the physical findings were not remarkable. The electrocardiograms showed ventricular premature contractions. This cardiac finding was apparently the result of excessive smoking.

The blood. The red blood count was 5,200,000 per cubic millimeter. The white blood count was 8,600 per cubic millimeter. Hemoglobin 76 per cent (Sahli). A blood smear stained by Wright's technique showed sausage shaped cells here and there but no very long ones. There was a rare microcyte. The average size of the erythrocytes was normal. There was very slight filamentation. One typical sickle cell was seen. Another fresh sealed preparation on January 25, 1927, showed sausage cells at fairly frequent intervals, one sickle cell, but no 


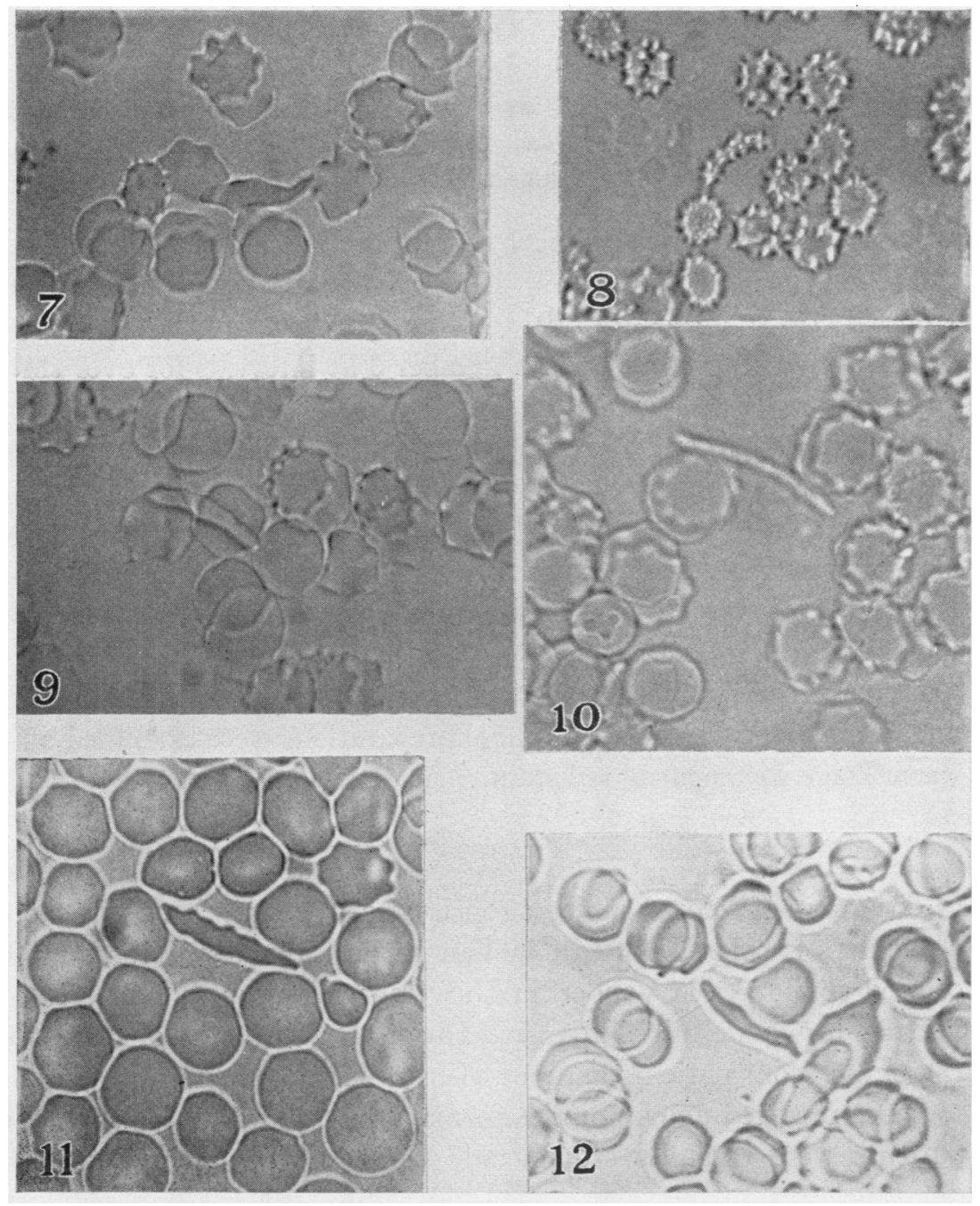

Fig. 7. Microphotograph of a Fresh Sealed Preparation of the Blood FROM SUbJECT 2, M. C. $\times 1000$

Fig. 8. Microphotograph of a Fresh Sealed Preparation of the Blood From SUbJeCt 2 , M. C. $\times 800$

Fig. 9. Microphotograph of a Fresh Sealed Preparation of the Blood From Subject 3, H. B. McS. $\times 1000$

Fig. 10. Microphotograph of a Fresh Sealed Preparation of the Blood FROM SUbJECT 4, J. C. McK. $\times 1300$

Fig. 11. Microphotograph of a Fresh Sealed Preparation of the Blood FROM W. P. (COLORED). $\times 1000$

Fig. 12. Microphotograph of a Fresh Sfaled Preparation of the Blood FROM E. W. (COLORED). $\times 1000$ 
filamentation. A rare microcyte was seen. Another smear examined at the same time showed essentially the same findings. Icteric index was 4. Figure 10 shows the type of cell found in this subject.

Inasmuch as latent sickling had been well established in cases of sickle cell anemia by Emmel (1917), Sydenstricker, Mulherin and Houseal (1923), and Huck (1923), observations were made on a fresh sealed preparation from subject number 3 at intervals for over three days, and no true increase in the abnormal cells was found. The preparation was kept at room temperature. In subject number 4 there seemed to be some, but not marked increase, in the abnormal cells about 28 hours after the examination. This preparation was also kept at room temperature. There was nothing comparable in this respect, however, with the findings which have been reported in true sickle cell anemia.

Phagocytosis was looked for in two of these subjects (subjects 2 and 3) and none was noted. These preparations were examined on a warm stage with neutral red stain.

\section{NEGROES SHOWING CHANGES IN RED BLOOD CELLS}

The group of colored subjects consisted of Meharry Medical School students, 41; colored patients in Vanderbilt University Hospital, 50; colored employees in Vanderbilt University Hospital, 7; and colored visitors in Vanderbilt University Hospital, 2; a total of 100. Of these, five (four patients and one visitor) showed phenomena similar to those reported above for the normal white subjects. Two of the patients were carefully studied and their findings are reported in detail below. In the case of the other subjects it was impossible to make several examinations.

\section{Colored patients showing sickling phenomena}

One of these patients, W. P., was 44 years of age and had cardiac hypertrophy and myocardial failure as shown clinically and at the postmortem table. The second of these patients, E. W., was 45 years of age and was suffering principally from chronic bronchitis. She also had syphilis and hypertension.

The blood of $W . P$. A fresh sealed preparation examined February 
18, 1927, showed one sickle cell and an occasional sausage form. There was mild filamentation. Another fresh sealed preparation was examined on February 24, 1927, and showed definite but not marked changes in the red blood cells. Two long narrow cells were seen, one of these being nearly three times as long as the average diameter of an erythrocyte. Other less pronounced sausage forms were observed. No true sickle cells were seen. There was mild filamentation. A smear stained by Wright's technique showed the red cells to be slightly achromic and an occasional cell basophilic. There was no stippling. The variations in size were normal except that there was a rare microcyte. There were no macrocytes. The principal variation in shape was toward the sausage forms. These were frequently found, were quite characteristic, and the longest were about twice the diameter of an average red blood cell. Two sickle cells were seen. There was mild filamentation. Platelets were normal. There was no evidence of phagocytosis. Red blood cell count 4,023,000 per cubic millimeter; white blood cell count 6,900 per cubic millimeter; hemoglobin 62 to 65 per cent. Icteric index 5. On February 28, 1927, a fresh sealed preparation, stained with neutral red and examined on a warm stage, showed active phagocytosis of the red blood cells by polymorphonuclear neutrophiles but no phagocytosis by the monocytes. Figure 11 shows the type of elongated red blood cell found in this patient. Special examination was made for latent sickling as described by Emmel (1917), Sydenstricker (1924), and Huck (1923). No increase in the deformed erythrocytes was noted on the following day but on the second day they seemed to have increased, but not so strikingly as described in cases of sickle cell anemia.

The blood of $E$. W. A fresh sealed preparation examined on February 18,1927 , showed occasional sausage forms. No sickle cells were seen. There was mild filamentation. A similar preparation on February 24, 1927, gave similar findings. Red blood cell count $3,900,000$ to $4,500,000$ per cubic millimeter; white blood cell count 5,500 to 8,900 per cubic millimeter; hemoglobin 64 to 75 per cent. The blood Wassermann was positive. A stained smear showed slight achromia of the red blood cells. There was moderate basophilia. There were slight variations in size, the average red cell being normal in size. There were no microcytes. There were slight 
variations in shape, the distinct tendency being toward mild sausage forms, which were found fairly frequently. There was mild filamentation. No stippling was present. No phagocytosis was found. No very long, slender sausage forms were seen but there was one which in length was about one and one-fourth times the diameter of the average red blood cell. The platelets were abundant. Reticulated count was two-tenths of one per cent. Icteric index was 3. On February 28, 1927, a fresh sealed preparation stained with neutral red showed both polymorphonuclear eosinophiles and neutrophiles containing ingested red blood cells. Figure 12 illustrates typical red blood cells found in this case. Latent sickling was searched for in this case also and no evidence of this was found on either the first or second day after the preparation was made. There were frequent crenated, short, narrow cells on the day following the taking of the preparation and again on the third day.

Of the two other colored patients showing these peculiar cells, one had gonorrhea and the other had tuberculous peritonitis, pulmonary tuberculosis and congenital syphilis.

\section{DISCUSSION}

Since the report by Herrick (1910) many cases of sickle cell anemia have been observed and carefully studied. The data in the literature indicate that this disease is a definite clinical entity peculiar to the colored race. Sydenstricker and Huck have been especially active in the study of this disease and a full discussion of it may be found in their papers. From an analysis of the literature the principal demands for a diagnosis in so far as the blood is concerned are the following findings: (1) The presence of sickle shaped cells in varying numbers in fresh sealed preparations. (2) "Filamentation" of the red blood cells. (3) The presence of long narrow red blood cells in fresh sealed preparations. (4) Phagocytosis of red blood cells by mononuclear cells. The literature has been remarkably free from any mention of the occurrence of the sickle cells and phagocytosis of red blood cells by mononuclear cells in abnormal or anemic white subjects.

Bishop (1914) described the blood findings in an Englishman 41 years of age. In this subject about 75 per cent to 80 per cent of 
the erythrocytes were elliptical in shape. The other blood findings in this case were essentially negative. The sister of this patient presented a similar blood picture. Huck and Bigelow (1923) reported two white cases presenting blood findings similar to those of Bishop's cases. Castana (1925) reported an infant of 15 months who showed a large number of "gigantocytes," the majority of which were halfmoon shaped, and a few of which were sickle shaped and thread formed. $\mathrm{He}$ referred indiscriminately to two processes which are obviously not closely related. One of these was vacuolization of red blood cells, which has been described by Schilling-Torgau (1911) and Leede (1912). The second process was that of sickle cell anemia as described by Sydenstricker and others. Evidently he did not recognize the difference in the phenomena discussed by the above authors. His description leads one to believe that he has found true sickling phenomena, but his confusion of the two processes as stated above makes one accept this conclusion with some reservation. Furthermore, there is no specific statement that the case reported belongs to the white race, though the natural assumption is that the child was an Italian.

Cooley and Lee (1926) studied 400 colored patients for the presence of sickling phenomena and found sickle cells in 30 , this number being seven and one-half per cent of these cases. They stated that in regard to the children in their positive group "in general, there was nothing in the illnesses, symptomatology, physical findings, or clinical course to distinguish any of these 28 children from the ordinary negro patient, except the presence of sickle cells." They did not make any statement as to the usual number of sickle forms which they found in the cases reported. In no case did they find any phagocytosis of the red blood cells by mononuclear leucocytes. In regard to the degree of anemia in the two types of cases, they stated that "while moderate anemia seems to be the rule among our colored children, there is practically no difference in this regard between those with and those without sickle cells." Their findings of sickle cells represent a much higher percentage than previously reported.

The history of our first case described in this paper is difficult to evaluate. The patient remained in the hospital for such a short time that extensive observations could not be made. The neuro- 
logical symptoms were thought, by a neurological consultant, to be evidence of posterior column degeneration but there was probably a definite hysterical element, also, as noted in the findings on physical examination. If there was cord degeneration, could this have been due to the type of anemia which the patient had? Certainly she did not have pernicious (Addison's) anemia, the usual form of anemia with which cord changes occur.

The blood findings were of particular interest and seem to have been those typically found in mild cases of sickle cell anemia, sickle- and sausage-shaped red blood cells, filamentation and phagocytosis being present. There must be some caution in calling this sickle cell anemia because no evidence of negro blood could be obtained. The familial tendency is of interest, one brother, one sister, and a niece presenting similar though less marked findings. Special attention was paid to the question of admixture of negro blood in the family and no evidence of this could be obtained. On the maternal side, the great-great-grandmother came from Spain and the great-greatgrandfather from France. The great-grandparents came to Sumner County, Tennessee, and the family has remained there until the present. On the paternal side, the ancestry was Scotch-Irish, and the great-grandparents are thought to have settled in Virginia, the family later moving to Tennessee.

Approximately 3 per cent of the normal white adults and 5 per cent of 100 negroes. (including both normal and sick individuals) in this series showed some deformity of the red blood cells, some of which seemed to be similar to those described in sickle cell anemia. Definite sickle forms were seen and, in addition, both long slender sausage forms and filamentous forms occurred. Questions naturally arise as to the etiological and clinical significance of these cells. Some of them were morphologically identical with those seen in sickle cell anemia, although these typical sickle cells were not present in as great numbers as were those of the slender sausage type, and we must raise the question as to whether these abnormal cells, occurring in apparently normal individuals or in patients suffering from some condition obviously unrelated to typical sickle cell anemia, have any relationship to the cells of true sickle cell anemia. There are several observations which indicate that these two types of cells have a similar if not wholly 
identical etiology. First, in typical cases of sickle cell anemia, slender, elongated red blood cells are seen admixed with the typical sickle cells. Second, in most of the individuals in which the sausage cells were found, there were also typical sickle cells. Third, both types are characterized by the formation of slender filamentous processes which become free in the cytoplasm. Fourth, transitional forms have been seen between the two types. It seems possible, therefore, that the etiological factors involved in the production of these two types of cells are similar.

Various theories have been advanced as to the etiology of the true sickle cell forms, but no attention has been paid to the possible relationship between the different types referred to above. Emmel (1917) has advanced the hypothesis that the transformation of the red blood corpuscles into the sickle-shaped elements is due in part at least to an -accentuated or abnormal activity of the same factors which in normal hematogenesis are involved in the transformation of the original spherical erythrocytes into biconcave disk-shaped forms. Sydenstricker, Mulherin and Houseal (1923) stated that "previous.observers, in the absence of pathological examination of the cases and of any etiologic agent that could be discovered, have been inclined to ascribe the peculiar poikilocytosis present in this condition to changes that took place in the blood after the cells reached the peripheral circulation." These observers found cells in the marrow which they described as "sickle shaped, filiform and otherwise abnormal erythroblasts, with erythrocytes to correspond to those various types," and accordingly, they thought that these findings justified the conclusion that sickle cells seen in the peripheral blood were not the result of changes that went on in the circulation or in the splenic sinuses, but that these cells were performed in the marrow as the result of some primary fault of erythropoiesis. Huck (1923) has suggested the theory that the sickling of the red blood cells is due to something inherent within the cells and not to any substance in the serum. He further thought that it might be a surface tension phenomenon. Graham (1924) advanced the tentative working hypothesis in regard to sickle cell anemia that the condition might consist in an underlying status, determined primarily by deeply rooted racial characteristics and brought into clinical evidence in 
occasional persons through the immediate action of toxic, metabolic or infectious exciting agents. He stated that there was some evidence in favor of the streptococcus being the immediate causative factor. Josephs (1927) has shown that the element responsible for sickling is in the plasma, since he has found that the abnormal erythrocytes of sickle cell anemia resume their normal shapes when washed sufficiently. Hahn and Gillespie (1927) have advanced evidence which indicates that "sickle cell formation in vivo is probably induced or increased by anoxemia." They think, however, that "the only specific cause for active sickle cell anemia is the unique hereditary anomaly of the red corpuscles which predisposes to it." However, the exact causative factor remains unknown.

Assuming that the factors which produce sickle and sausage cells are both identical or closely related, and since evidence that this process is present in an appreciable number of otherwise normal white adults has been obtained, it would seem that there may be an unknown factor at work even in the white race. But if this is true, apparently there is a definitely inhibitive force present also, for were this not the case, with this appreciable number of subjects having this unknown or $x$ factor, many outstanding cases of sickle cell anemia in white subjects should occur. Are we to assume that these apparently normal white adults have quiescent sickle cell anemia? Do they really represent the earliest form of this condition, an intermediate form being represented by the white patient (L. B. S.)? It would seem possible that these individuals have a very mild form of the condition necessary for the production of sickle cell anemia. That they will ever develop the disease is doubtful. However, it may be that this $x$ factor would become prominent were there to be an admixture of white and colored bloods, that is, the factor of sickling may become more prominent due to the interbreeding. This, of course, is highly speculative. It should be noted that only one case of sickling was found among the 42 apparently normal colored subjects examined. The other four cases found were among colored patients representing a variety of pathological conditions.

The picture presented in the two colored patients ( W. P. and E. W.) is very similar to that reported in the normal white adults. The main differences are to be found in the presence of phagocytosis, the anemia 
and the tendency in one case to increased sickling phenomena on standing at room temperature. The blood of these cases had many points in common with that of sickle cell anemia but differed in that it did not contain as many typical cells as are found in this condition and the phagocytosis instead of being by the monocytes was by the polymorphonuclear neutrophiles. In addition to this, these patients were suffering from other pathological conditions and did not present the clinical picture associated with sickle cell anemia. The cells found in these cases seem to fall midway between those seen in normal white adults and in case $1, \mathrm{~L}$. B. S., which occurred in the family with Spanish blood. It is not possible to say that the same process is represented in each case but the evidence at present points toward this conclusion.

Since Cooley and Lee (1926) reported that at incubator temperature the sickle cells disappeared rapidly from the blood leaving the round cells behind, two long sausage forms were placed under oil immersion on a warm stage and examined at intervals for about 30 hours. No change was noted in the shape of these cells. In so far as this one observation goes, it would seem that we were not dealing with cells that changed shape at incubator temperature.

No phagocytosis of red blood cells has been observed in the group of cases among the normal white subjects. Nor has latent sickling been observed among normal white subjects. The question of heredity of these characteristics has not been settled, because the families of these subjects are located elsewhere.

Stained preparations are not so reliable as unstained ones in distinguishing sickle cells, but the final stained blood smears in each of the white persons show cells suggesting the phenomena, sausage cells being constantly present. I am inclined to believe, that fresh sealed preparations from cases showing sausage cells will usually, if carefully studied, show the associated sickling phenomena reported in this paper. No polychromatophilia was found in any of the white cases, and for this reason, counts of the reticulocytes were not made. Neither was there any evidence of any hemolytic process being present as the icteric index was within the normal limits in the two cases in which this test was made. For this reason and because no previous observers, Mason (1922), Moser and Shaw (1925), Cooley and Lee 
(1926) and Huck (1923), had found the fragility test particularly abnormal in sickle cell anemia, this test was not done.

This opportunity is taken to express appreciation for the many helpful suggestions of Dr. Robert S. Cunningham, who has observed the blood in most of the cases reported in this paper.

\section{SUMMARY}

1. Sickle-shaped, sausage and filamentous red blood cells have been shown to be present in some, otherwise normal, white adults.

2. A corresponding series of negroes has shown these abnormal cells in approximately the same proportion (about 2 per cent).

3. A case presenting most of the blood findings generally associated with sickle cell anemia has been found in a white woman.

4. The sickling phenomena have been found in certain members of her family.

5. Evidence of sickling of red blood cells has been found in 6 white adults and in 4 colored adults suffering with various diseases.

6. The cells of negro patients showed slight evidence of latent sickling and definite phagocytosis of red blood cells by polymorphonuclear neutrophiles.

7. The sickle cells in one of the colored cases did not change their shape on being kept at incubator temperature.

\section{BIBLIOGRAPHY}

Bishop, F. W., Arch. Int. Med., 1914, xiv, 388. Elliptical Human Erythrocytes. Castana, V., La Pediatria, 1925, xxxiii, 432. I Gigantociti e le Anemie Semilunari.

Cook, J. E., and Meyer, J., Arch. Int. Med., 1915, xvi, 644. Severe Anemia with Remarkable Elongated and Sickle Shaped Red Blood Cells and Chronic Leg Ulcer.

Cooley, Thos. B., and Lee, Pearl, Amer. Jour. Dis. Children, 1926, xxxii, 334. The Sickle Cell Phenomenon.

Dresbach, M., Science, 1904, xix, 469. Elliptical Human Red Corpuscles.

Dresbach, M., Science, 1905, xxi, 473. Elliptical Human Erythrocytes. (A Supplementary Statement.)

Emmel, V. E., Arch. Int. Med., 1917, xx, 586. A Study of the Erythrocytes in a Case of Severe Anemia, with Elongated and Sickle Shaped Red Blood Corpuscles. 
Graham, George S., Arch. Int. Med., 1924, xxxiv, 778. A Case of Sickle Cell Anemia with Necropsy.

Hahn, E. Vernon, and Gillespie, Elizabeth B., Arch. Int. Med., 1927, xxxix, 233. Sickle Cell Anemia. Report of a Case Greatly Improved by Splenectomy. Experimental Study of Sickle Cell Formation.

Herrick, J. B., Arch. Int. Med., 1910, vi, 517. Peculiar Elongated and Sickleshaped Red Blood Corpuscles in a Case of Severe Anemia.

Huck, J. G., Bull. Johns Hopkins Hosp., 1923, xxxiv, 335. Sickle-cell Anemia.

Huck, John G., and Bigelow, Rena M., Bull. Johns Hopkins Hosp., 1923, xxxiv, 390. Poikilocytes in Otherwise Normal Blood.

Josephs, Hugh W., Bull. Johns Hopkins Hosp., 1927, xl, 77. Sickle Cell Anemia.

Leede, W. H., Jahrucher d. Hamburgischen Staatkrankenanstalten, 1912, xvii, 1. Gigantozyten bei Malaria.

Mason, V. R., Jour. Amer. Med. Ass., 1922, lxxix, 1318. Sickle Cell Anemia.

Minot, Geo. R., and Lee, Roger I., Nelson Loose-Leaf Living Medicine. Vol. IV. Diseases of the Blood:

Moser, R. A., and Shaw, W. J., Jour. Amer. Med. Ass., 1925, lxxxiv, 507. Sickle Cell Anemia in Northern Negro.

Sydenstricker, V. P., Jour. Amer. Med. Ass., 1924, lxxxiii, 12. Further Observations on Sickle Cell Anemia.

Sydenstricker, V. P., South. Med: Jour., 1924, xvii, 177. Sickle Cell Anemia.

Sydenstricker, V. P., Mulherin, W. A., and Houseal, R. W., Amer. Jour. Dis. Children, 1923, xxvi, 132. Sickle Cell Anemia. Report of Two Cases in Children with Necropsy in One Case.

Schilling-Torgau, Arch. f. Schiffs- und Tropen-Hygiene, 1911, xv, 364. Specifische Gigantozyten (Corps en demi-lune) bei Malaria. 